\title{
UNDERSTANDING SENIOR TRAVELER'S BEHAVIOR WHEN CONSUMING TOURISM AND HOSPITALITY PRODUCTS
}

\author{
Serli Wijaya \\ Program Manajemen Perhotelan, Fakultas Ekonomi Universitas Kristen Petra \\ e-mail: serliw@peter.petra.ac.id
}

\begin{abstract}
The dramatic increase of the number of seniors who undertake tourism activities pose both opportunities and challenges for tourism and hospitality business operators. Like any other groups of consumers, senior segment has specific wants and preferences when consuming travel-related products and services. Thus, it is important for the industry stakeholders to understand the behavior of this segment. This paper aims to examine senior travelers' behavior and to portray the perspectives of the academia, industry professionals, and government tourism bodies in responding the segment with marketing strategies directed to them.
\end{abstract}

Keywords: Senior traveller, consumer behavior, tourism, hospitality

The world population is becoming collectively older, as a result of low birth rates and a steadily growing proportion of people who are living longer, healthier, and more productive than ever before. The seniors represent one of the fastest growing segments of the population. As can be seen at the figures below, the number of $60+$ age group grows markedly from only 8 percent of total world population in 1950 , to 10 percent in year 2000, while in 2050 the figure is projected to achieve 21 percent of total world population (UN, 2000).

World Population by Broad Age Group: Estimates and

Medium Variant Projections: 1950, 2000 and 2050
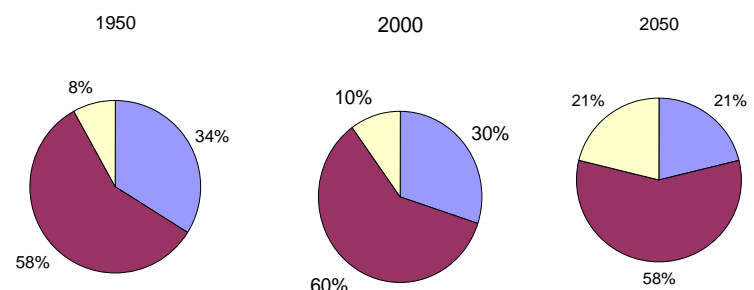

$\square 0-14 \square 15-59 \square 60+$

World Population Prospects: The 2000 Revision, Volume III: Analytical Report

Further, Francese (2003), and Teaff and Turpin in 1996 (cited in Baloglu and Shoemaker, 2001) contend that seniors are extremely potential segment to be targeted, especially for tourism and hospitality businesses. This is not only because of its huge market size, but also as the older people have more time to travel and are more willing to spend a large portion of their discretionary income on travel and leisure activities than any other groups of consumers.
This paper aims to examine the behavior of senior travelers which are demonstrated when undertaking tourism activities from the perspectives of academic scholars, industry experts as well as government bodies in responding the emergence of senior market.

For the purpose of the study, this paper will refer to different secondary data sources, namely from academic journal articles, articles from the industry professionals and/or associations, and from studies conducted by government institutions which discuss the senior travelers' behavior.

\section{THE IMPORTANCE OF UNDERSTANDING THE SENIORS' BEHAVIOR}

It is crucial for every business to satisfy the customers with products and services which meet their needs and preferences. To do so, companies need to understand the behavior of their target market thoroughly, as different segment has different needs and preferences, including the senior segment as well.

There are many misleading perceptions attached about senior people. Most service providers still stereotype seniors are somewhat frail, often unwell, and are generally uninterested in new things and experiences (Muller and O'Cass, 2001). Even, there are many myths associated with older people, such as that the senior market is dull, slow, old, and static (Walker, 2002; Adler, 1996). As a consequence, they are incapable in conducting any travel activities.

In fact, not all those perceptions are true. In many cases, today's seniors much differ from their previous cohorts. Their behavior in consuming products and services including tourism products and services has changed as well. For example, according to Tourism 
Queensland, about three quarters or 75 percent of Australian seniors traveled in 1998, and 80 percent of them stating that they want to travel now or in the near future. Likewise, as noted by the Australian's Bureau of Tourism Research, internationally, there were almost 600 million tourists aged 60 or over in 1999. This figure is likely to increase to at least 2 billion by the middle of the century (2003). Moreover, lots of evidence suggests that people over the age 55 in developed countries such as in the United States and Germany exhibit different travel behavior compared to the seniors in few decades ago. Today, they tend to go longer distances, and stay away longer than any other age groups (Javalgi, Thomas, and Rao, 1992; Lohmann and Danielsoon, 2001).

Therefore, considering the changes of senior market, it is very important for every stakeholder in the tourism and hospitality industry to understand the behavior of the seniors when undertaking tourism activities or when purchasing travel-related products and services. Once it can be identified, they can adjust the marketing strategies so as to fit with the expectations of the group.

\section{SENIOR TRAVELER'S BEHAVIOR WHEN UNDERTAKING TOURISM ACTIVITIES}

\section{Travel Motivation}

Motivation is a basis for understanding why tourists behave in certain ways as it reflects the intrinsic needs of each individual. Motivation is closely related to the benefits sought by tourists when they undertake tourism activities (Mill, 1992:17). In the reality, tourist's motivation can be very wide range and complex. They might seek to satisfy not only one single need but also a number of distinct needs simultaneously (Gonzalez and Bello, 2002). Therefore, it is important to know what major motivators which drive tourists for traveling.

Mayo and Jarvis state that travel motivation generally could be divided into four major categories, (1) physical motivators, such as physical rest, sports participation, relaxing, and health considerations; (2) cultural motivators, which include the desire for knowledge of other countries - music, arts, and religion; (3) interpersonal motivators, for instance to meet new people or to make new friendships, to visit friends or relatives, and to escape from routine; and (4) status and prestige motivators, which include the desire for recognition, appreciation, and a good reputation (cited in Ross 1998, p. 20).

There has been extensive research undertaken to examine senior travelers' motivation. For examples, study by Romsa and Blenham in 1989 found that German's older travelers placed a high priority on wanting to see friends or relatives as their motivation to travel (quoted in Lieux, Weaver, and McCleary, 1994). Moreover, Guinn (1989) observed that his sample of Texas seniors traveled primarily for the benefits of rest and relaxation. Other motivation identified by Guinn included opportunities for social interaction, physical exercise, learning, excitement, and nostalgia. Likewise, Hagan and Uysal (1991) studied a large group of seniors across the United States and noted that the opportunities for socialization, exposure to novel situations and escape from the stresses of daily life were powerful motivators for traveling (cited in Zimmer, Brayley, and Searle, 1995).

\section{Information Searching Process}

Senior travelers typically spend more time to plan their holiday trips than other younger groups. They use a number of different sources to search for tourism products alternatives before making holiday purchase decisions. Research conducted by Prideaux, Wei, and Ruys (2001) illustrated that most Australian's senior travelers consider word of mouth from family, relatives, and friends as the most important sources of information, followed by marketing brochures from the service providers, travel agents, and other sources such as Senior Card Business Directory. It is make sense since tourism and hospitality products are considered as high-involvement and high-risk products, thus, before making the purchase decisions, consumers usually seek the information about how the products perform according to other people's experiences. In this case, word of mouth is considered as the most believable and reliable information sources.

In addition, the result of the National Visitor Survey undertaken by Bureau of Tourism Research in 2001 showed that recently, the Australian's senior travelers are likely to be more active and even are more capable to adopt technological development when seeking the information for their holiday travel. They do not merely lean on travel agents or promotional brochures as the main sources of information. Rather, they also search for the information from the Internet, travel guidebooks, or from government tourist offices such as Visitor Information or Tourism Commissions (Tourism Queensland, 2003). The similar trend is also indicated in Germany, where Lohmann and Danielsson's study in 1999 revealed that 68 percent of today's Germans aged 70 years old prefer to organize their main holiday 
trip in 1999 by themselves rather than lean on the helps from either travel agencies or tour operators (2001).

However, the result might be different for senior group from non-Western countries, such as Asia, Africa, or Middle-East regions. In these regions, the availability and accessibility of the information are relatively more limited for instance the speed-quality of online or internet connection. The level of dependability on the travel agents to provide information related to tourism and hospitality services are relatively high. This phenomenon however is needed to investigate empirically to give more reliable information for service providers.

\section{FACTORS INFLUENCING HOLIDAY DESTINATION CHOSEN AND TYPES OF TOURISM ACTIVITIES UNDERTAKEN}

There are several factors which influence older travelers' decision to select the holiday destination visited. Zimmer, Brayley, and Searle (1995) did an empirical research in the United States to examine whether demographic characteristics of the seniors affect their decision to choose holiday destination or not. The result showed that factors such as income, education, rural residency, willingness to spend money on recreation, and health status proved to influence the choice of destinations amongst the seniors. For instance, seniors who live in urban areas, who are better educated, have more money, tend to travel farther from their homes. On the other hand, those who have health problems tend to travel to the nearby U.S. tourist destinations.

Likewise, Prideaux, Wei, and Ruys (2001) present the research conducted by ACNielsen in 1998 which found that financial and health reasons are considered as the major constraints for the Australian's seniors to take travel activities far from their homes. The study revealed that most Australian's older tourists were more likely to travel intrastate (an average 3.2 trips per year) than interstate (1.6 trips per year) or overseas (1.2 trips per year).

However, as a result of the medical development, today's senior travelers are in better health conditions, hence, they are likely to go traveling to farther destinations than ever before. This fact can be seen in Lohmann and Danielsson's research (2001) which illustrate that the majority of German's senior tourists prefer to choose and to plan to travel abroad instead of traveling to the neighborhood countries such as Austria, Italy, or Spain, and the figure is projected to increase from 72 percent in 1999 to 81 percent in 2020. Similarly, Muller and O'Cass' study show that the majority of older Australian's travelers in their study state that they prefer to visit islands, mountains, and outback as their most favorable holiday destinations (2001). Therefore, it can be said that there is a trend that today's senior tourists would like to engage in outdoor and more experiential activities than ever before.

Further, the emergence of drive tourism and motorcoach tour conducted by senior tourists in some Western countries can be seen as the facts indicating that trend above. In Australia for instance, drive tourism constitute an important sector of the tourism industry, where the number of Australian's older travelers which engage in this type of tourism activity has increased significantly in the past few years. Prideaux define drive tourism as "tourism that centers on traveling from an origin destination to a destination by car that is either privately owned or rented, and engaging in tourism-related activities during the journey" (quoted in Prideaux, Wei, and Ruys, 2001). Moreover, in the case of motorcoach tourism, Baloglu and Shoemaker (2001) point out that motorcoach tour groups are one of the fastest and consistently growing segments of travel and tourism in the United States where senior citizens represent 32 percent of the motorcoach market. Their research investigated the behavior of senior motorcoach travelers in Pennyslvania and found that this segment prefer their trips to be filled with more physical outdoor activities such as walking paths tour rather than common activities such as visiting historic sights and shopping.

\section{Lodging Preferences}

In selecting the type of accommodation used during their holiday trip, the seniors have different preferences or criteria to be considered compared to the other groups. The empirical study undertaken by Javalgi, Thomas, and Rao showed that hotels and motels dominate the accommodation preferences of the American's senior tourists whereas they less prefer to stay in campgrounds and caravan parks (1992). Similarly, study by Bureau of Tourism Research demonstrates that currently in Australia, many seniors prefer mid-priced accommodation to budget luxury accommodation. Three star hotels and motels are popular as they provide home comforts. Moreover, consumers state that hotels or motels' facilities design and layout are very significant in influencing their satisfaction towards the properties they stay with. For examples, ensuite bathrooms are desired by a majority of seniors. They also tend to avoid accommodation with stairs or where there is a long walk from the car park to check-in, or a long walk to their room. 
In addition, as seniors value safety and security factors relatively higher than any other groups of consumers, thus, they consider that the availability and proximity of medical assistance as another important facility which should be provided by the accommodation providers. (Tourism Queensland, 2003).

\section{Types of Transportation Used}

There are several factors which affect the seniors' decision to choose which type of transportation mode will be used either prior or during conducting travel activities. In Australia, where the distance is a significant factor, the majority of senior travelers choose to travel by car when intrastate journeys or short cross-border trips are undertaken. As distance increases, then, there is a tendency for the seniors to substitute travel by car with travel by plane (Prideaux, Wei, and Ruys, 2001). In line with the fact in Australia, Javalgi, Thomas, and Rao's study (1992) point out that in the United States, the most preferred means of travel overall for American's senior travelers is automobile. However, as the age increases, bus travel or plane is more favorable to be used for their pleasure trip.

Nevertheless, types of transportation selected not only depend on the geographical characteristics. Factors such as level of income should be taken into consideration as an influence factor. For instance, in Indonesia where level of income is relatively low, the consumers might choose to take a bus or train rather than airplane.

\section{INDUSTRY'S RESPONSES TOWARD SENIOR TRAVELERS}

Many service providers have recognized that senior market will emerge as a highly profitable segment in the future, hence, it should be taken into account when planning the marketing strategies. Some of them have been adjusting their products and services and employing different marketing strategies so as to fulfill the specific preferences of the seniors. For example, two of the Choice Hotels International's brands, Econo Lodge and Rodeway in 1993 created specific products aimed at active senior travelers by designing the Senior Rooms. This type of room features amenities that offer comfort and maintain the quality of life that the seniors are used to their own homes. Brighter lighting allows guests to see better; large-button telephones and TV remote controls provide easy operation of commonly used items; and lever handles on doors and faucets ensure these older guests can move about in the room without any great effort. As a consequence, both properties enjoy the dramatic increase of their room sales (Miller, 1996).

Likewise, as reported by Koss (1994), large hotel corporate such as Radisson Hotels International and Best Western International, and consortium such as Hospitality Franchise Systems, also offered special products and services to capture the older guests such as senior clubs and frequent-guest programs aimed for senior guests. As stated by Rochester, the Vice President of marketing of Radisson, hoteliers should change their perceptions that senior people are old, do not want to do much when they travel, and their concern is just about cheaper prices. Thus, Radisson has begun to explore and offered new leisure programs designed specifically for their senior guests.

Further, the positive response also exhibited by industry associations such as National Tour Association (NTA) in the United States. Their first industry research report on the senior market was issued in 1998. The report contains the projection of the new wave of older travelers who are more independent and prefer to undertake special interest or more challenging travel activities such as bird watching, hot-air ballooning and even white-water rafting. Therefore, tour operators should prepare and design tours and packages which are most fit with this demand (Rosso, 2001).

However, despite the responses demonstrated above, there are many service providers which still have wrong perceptions that senior travelers are very price-sensitive and look after merely cheaper prices when purchasing products and services. It can be indicated in the way they set the pricing strategies directed to the senior market, which emphasize mainly on price cutting, discounts or bargains. For instance, Schmedel (1999) describes that in the United States itself, nearly every major domestic airline and most foreign carriers cut 10 percent from any published fare for individual age 62 and older. Further, nine of the national airlines offer coupons that older travelers can exchange for bargain tickets, while four carriers have created travel clubs for senior where they can get additional discounts by becoming the club member. Many service providers think that by giving cheaper deals can boost the sales revenue from this segment, where in fact, it is not always true. This assumption can be misleading, especially when the company target senior segment whose higher level of income. For this group, price will not be a major driven factor influencing their purchase decision.

Javalgi, Thomas, and Rao based on their primary research suggest important points need to be considered for the service providers when they plan 
the promotion strategies aimed at senior market. For instance, as today's and future senior are more welleducated, thus, promotion and advertising programs directed to them might need to be more sophisticated and more consumer information-oriented than currently done (1992).

Moreover, Baloglu and Shoemaker showed three important aspects considered by the senior respondents of their research when they take motorcoach tour (2001). First, they state that price is just one of the concerns and not the important factor influencing their decision. Based on this fact, Baloglu and Shoemaker thus urge that the management needs to plan and set the price carefully and if necessary, to search how much money the seniors are willing to pay for motorcoach tour so as not to misjudge the market by giving them the wrong price. Second, the respondents state that they prefer lots of activities and visit different destinations during their long holiday. Hence, management needs to seek out new destinations visited and explore different leisure programs. Third, the seniors also like to build new friendships with other people besides their close friends or relatives during the trips. Consequently, it is crucial for the tour operators to have well trained tour guides whose good communication skills in order to build a friendly atmosphere amongst the travelers during the trips. Also, they should provide downtime for seniors to interact with each other to make new friendships.

\section{GOVERNMENT'S PERSPECTIVE SENIOR TRAVELERS}

Many studies have been undertaken by government institutions particularly in developed countries to examine the senior travelers. Some of these studies are provided for the industry to give them the current analysis of the segment so that they can improve their service to the seniors. For example, Tourism New South Wales in 1999 conducted a market research to investigate the behavior of Australian's senior travelers. The report which is named the Not Over the Hill report provided information on what seniors want in relation to accommodation, transport, motoring, leisure, tours, travel agents and other tourism products preferred by the seniors; how they want it, and how tourism businesses can position themselves to get benefits from this market (Tourism New South Wales, 2003).

Likewise, in 2002, Tourism Queensland also undertook a market research to gain better understanding of the seniors market especially regarding the needs and preferences of the seniors when consuming travel-related products and services. Research's result revealed that there is a great opportunity for the hospitality and tourism businesses as the number of both domestic and foreign seniors who travel to Australia will increase dramatically in the future, thus, the industry should well prepare for this upcoming wave. The study suggests that businesses which adapt their products and services to meet the needs of the seniors will get the optimum benefit from this growing market (Tourism Queensland, 2003). Both Tourism New South Wales and Tourism Queensland target the seniors as one of the segments captured in their strategic marketing planning for expanding either domestic or inbound tourism in Australia.

However, it can be said that the research conducted to investigate the senior market is very limited in the developed countries only. The governments in developing countries such as Asian countries seem like have not acknowledged yet that the senior market can emerge as one major segment which generates significant contribution in the national tourism industry.

\section{OPPORTUNITIES AND CHALLENGES - MANAGERIAL IMPLICATIONS}

The dramatic increase of the number of seniors who undertake tourism activities pose both opportunities and challenges for service providers to put great efforts to serve this market in the best way. First, although most of seniors feel their health is good, but health does become more of a concern with increasing age. Therefore, they will seek reassuring information on available medical facilities, opportunities for personal assistance, and health insurance when traveling. Second, finance is still considered as the greatest barrier to travel for seniors. While it does not always prevent travel, it does encourage senior market to budget carefully, travel selectively, and be conscious of value for money.

On the other hand, seniors are very loyal market and tend to return to operators who could provide good service. Seniors also listen to and value word of mouth recommendations offered by their friends and relatives. Hence, the service provided by one service provider is a very important component of the marketing strategies.

\section{CONCLUSION AND RECOMMENDATIONS}

The findings indicate that generally all stakeholders acknowledge the seniors as an extremely potential segment to be targeted and some have 
responded the seniors' needs and preferences quite well by designing special marketing programs for them. However, whilst the academia and the government analyse this segment's behavior from more comprehensive angles and offer alternatives to serve this segment better; the industry experts tend to be more practical and short-sighted. Thus, it is suggested that in order to serve the senior segment in better ways, the industry could gain benefit from the studies undertaken either by the academia or government tourism bodies.

Furthermore, in terms of the scope of the reserach on senior traveler behaviour, most of the research undertaken only focus on senior behavior in the context of Western countries. While cultural and social differences is considered as a major determinant factor in influencing people behaviour, thus, the efforts undertaken by government bodies and business operators might not the same or irrelevant in the context of Asian region. Therefore, future research on profiling senior travelers' behaviour could be implemented to examine the role of cultural and social differences.

\section{REFERENCES}

Adler, R. 1996, "Stereotypes Won't Work With Seniors Anymore", Advertising Age, November, 11, 1996.

Australian Bureau of Statistic. 2003, "Australian Social Trends 1999, Population Projection: Our Ageing Population" http://www.abs. gov.au/AusStats (visited 1 April, 2003).

Baloglu, S., \& Shoemaker, S. 2001, "Prediction of Senior Travelers' Motorcoach use From Demographic, Psychological, and Psychographic Characteristic", Journal of Travel Research, vol. 40, August, pp. 12-18.

Francese, P. 2003, “Top Trends for 2003”, American Demographics, Dec 2002/Jan 2003, pp. 48-52.

Gonzalez, M.A. \& Bello, L. 2002, "The Construct "Lifestyle" in Market Segmentation: The Behavior of Tourist Consumers", European Journal of Marketing, vol. 36, number 1/2, pp. 51-85.

Javalgi, R.G., Thomas, E.G., \& Rao, S.R. 1992, "Consumer Behavior in the US Pleasure Travel Marketplace: An Analysis of Senior and Nonsenior Travelers", Journal of Travel Research, vol. 30, Fall, pp. 14-19.

Koss-Lalia. 1994, "Hotels Develop Special Packages to Attract Senior Travelers", Hotel and Motel Management, vol. 209, issue 3, February 22, 1194, pp. 37.
Lieux, E.M., Weaver, P.A., \& McCleary K.W. 1994, "Lodging Preferences of the Senior Tourism Market", Annals of Tourism Research, vol. 21, no. 4, pp. 712-728.

Lohmann, M., \& Danielsson, J. 2001, "Predicting Travel Patterns of Senior Citizens: How the Past May Provide A Key to the Future", Journal of Vacation Marketing, vol. 7, no. 4, pp. 357-366.

Mill, C.R. 1992, The Tourism System: An Introductory Text, $2^{\text {nd }}$ edn, Prentice Hall.

Miller, J. 1996, “Golden Opportunity”, Hotel and Motel Management, vol. 21, issue 6, April, pp. 45-46.

Muller, T.E., \& O'Cass, A. 2001, “Targeting the Young Heart: Seeing Senior Vacationers the Way They See Themselves", Journal of Vacation Marketing, vol. 7, no. 4, pp. 285-301.

Prideaux, B., Wei, S., \& Ruys, H. 2001, "The Senior Drive Tour Market in Australia", Journal of Vacation Marketing, vol. 7, no. 3, pp. 209-219.

Ross, F.G. 1998, The Psychology of Tourism, $2^{\text {nd }}$ edn, Hospitality Press Melbourne. Melbourne.

Rosso, L. D. 2001, "NTA Readies for Coming Wave of Baby Boomers", Travel Weekly, Jan, 15, 2001, p. 16.

Schmedel, S.R. 1999, "Bargains on The Fly: Airline Discounts for Older Travelers Are Anything But Equal", The Wall Street Journal, Jun, 7, 1999, pp. 12-19

Tourism Queensland, 2003, "Grey Tourism (Seniors)" http://www.tq.com.au (visited 1 May, 2003).

Tourism New South Wales. 2003, “A Close-Up Look at the Senior Market: Senior Tourism Research - Not Over the Hill. Just Enjoying the View" http://corporate.tourism.nsw.gov.au/corporateli ve/downloads/research (visited 1 May, 2003).

United Nations Population Division, 2000, "World Population Prospects: The 2000 Revision, Volume III: Analytical Report",http://www.un. org (visited 15 July 2004).

Walker, M. C. 2002, "Marketing to Seniors: Debunking Myths of The Senior Market", http://www.marketingtoseniors.info/marketingt oseniorsdebunkingmyths (visited 10 April, 2003)

Zimmer, Z., Brayley, R. E., Searle, M. S. 1995, "Whether to Go and Where to Go: Identification of Important Influences on Seniors' Decisions to Travel", Journal of Travel Research, Winter, pp. 3-10. 